\title{
Upflow Filtration System Using Fiber-Ball Filter Media for the Treatment of Nonpoint Pollution
}

\author{
Junho Lee ${ }^{1,+\oplus} \cdot$ Daesik Song $^{2 \oplus}$ \\ 'Division of Civil, Environmental \& Urban-Transportation Engineering, Korea National University of Transportation \\ ${ }^{2}$ Jayeon Environment, Co., Ltd.
}

(Received January 26, 2021; Revised February 15, 2021; Accepted February 23, 2021)

Objectives: The objective of this study is to investigate the performance of the fiber-ball media upflow filtration system for non-point pollutants treatment.

Methods: The additional air backwashing nozzle were installed between upper and lower fliter media cartridge. The effect of feed SS concentration, surface overflow rate, retention time, head loss on the removal efficiency were investigated respectively. Particle size distribution, SEM, and backwashing effect were also analyzed.

Results and Discussion: The operated of upflow filter mean retention time, mean head loss were 1.99 min, 7.2 $\mathrm{cm}$. On condition of SOR $480 \mathrm{~m}^{3} / \mathrm{m}^{2} /$ day, results indicate that the range of removal efficiency of turbidity and SS were $76.8 \sim 93.21 \%$ (mean $88.3 \%$ ) and $85.4 \sim 97.9 \%$ (mean 92.7\%), respectively. The effluent turbidity and SS were under $15 \mathrm{NTU}, 20 \mathrm{mg} / \mathrm{L}$, respectively.

Conclusions: Since turbidity can be continuously monitored in a filtration non-point pollution treatment system, turbidity can be used as a operation factor in evaluating operating conditions. The particle size the effluent larger than the influent was due to bonding, collision and adsorption between particles in the pores of the filter media. SEM analysis showed that after backwashing, very fine particles in the filter medium were not removed but adhered to the fiber yarn and remained. The average recovery rate of fiber-ball media filtration was $88.7 \%$, which is evaluated as excellent in backwashing.

Keywords: Fiber-Ball Media, Non-Point Pollutant, Up-Flow Filtration, Particle Size Distribution, Backwashing, Recovery Rate of Media

The Korean text of this paper can be translated into multiple languages on the website of http:/jksee.or.kr through Google Translator. 


\title{
연구논문
}

\section{섬유볼 여재 상향류 여과시스템에 의한 비점오염처리}

\section{이준호 ${ }^{1+\oplus} \cdot$ 송대식 $^{2 \odot}$}

\author{
${ }^{1}$ 한국교통대학교 건설·환경·도시교통공학부 \\ ${ }^{2}$ 자연환경(주)
}

목적: 본 연구의 목적은 비점오염물질 제거를 위해 섬유볼 여재를 상향류식 2 단 여과시스템의 처리특성을 분석하 고 평가함에 있다.

방법: 상단, 하단 여과칼럼 사이에 역세척 노즐을 추가적으로 설치하였다. SS 농도변화, 수면적부하율, 체류시간, 손실수두 등 운전조건에 따른 처리효율에 미치는 영향을 분석하였다. 또한, 입경분포, SEM 분석, 역세척 효과 등 도 분석하였다.

결과 및 토의: 여과칼럼 평균 체류시간은 $1.99 \mathrm{~min}$, 수두손실은 평균 $7.20 \mathrm{~cm}$ 로 분석되었다. $\mathrm{SOR} 480 \mathrm{~m}^{3} / \mathrm{m}^{2} / \mathrm{day}^{2}$ 운전조건에서 유출수 처리효율 범위는 탁도 76.8 93.2\%(평균 88.3\%), SS 85.4 97.9\%(평균 92.7\%)로 분석되었 다. 유출수 탁도는 $15 \mathrm{NTU}, \mathrm{SS} 20 \mathrm{mg} / \mathrm{L}$ 이하로 분석되었다.

결론: 여과형 비점오염 처리시스템에서 탁도는 연속 모니터링이 가능하므로 운전상태 평가에 주요 인자로 활용이 가능하다. 여과과정에서 여재 내 포획되어 입경이 감소하는 경향과 여재 공극 내에서 입자 간 충돌, 흡착 등으로 입자 간에 결합이 발생하여 유입수 입경보다 큰 유출수 입경분포를 나타내는 것으로 판단된다. SEM 분석결과 역 세척 후에는 여재 내 매우 미세한 입자들은 제거되지 않고 섬유사에 부착되어 잔류되는 것으로 나타났다. 잔류고 형물 물질수지 분석을 통해 산정한 섬유볼 여재 여과 회복율은 평균 $88.7 \%$ 로 역세척 효과가 우수한 것으로 평가 된다.

주제어: 섬유볼 여재, 비점오염물질, 상향류 여과, 입경분포, 역세척, 여재회복율

\section{1. 서 론}

대표적인 도시 비점오염원인 강우유출수 내 $100 \mu \mathrm{m}$ 이하 미세입경을 가진 입자는 큰 비표면적과 높은 반응성을 가지 고 있어 오염물질의 주된 이송매체 역할을 한다. ${ }^{1,2)}$ 장치형 비점오염처리시설 중에서 여과형 비점오염처리장치는 집적 화, 고효율 등의 장점으로 현재 적용성이 높다. ${ }^{3)}$ 여과형 처리 시스템에서 발생하는 막힘을 최소화하기 위한 여재 특성, 역 세척 기술 등에 대한 연구들이 진행되고 있다. ${ }^{4-6)}$ Reddy 등은 도시 비점오염물질을 처리하기 위한 여재 선정 기준을 여재 조성의 일관성, 사용이 용이하고 제품화된 여재, 저비용, 친환 경, 내구성, 투수성, 시공 용이성, 효과적 오염물질 제거 등을 제시하였다. ${ }^{7}$ 다양한 소재, 형태의 섬유사를 이용한 여과 기 술들이 개발되고 있다. 섬유사 여과는 여재 압축율 조정으로 입자 제거효율을 높일 수 있고 유입수 농도에 가변적 운전이 가능하다. 일반적으로 섬유사 여재의 압축율을 높이면 여과 효율도 증가하지만 압력손실이 증가하는 특성을 나타낸다. ${ }^{8)}$
$\mathrm{Gao}$ 등은 섬유볼 여재를 이용하여 고탁도 지표수 처리를 위 해 응집제 종류 및 주입농도, 여과속도 등 운전조건이 유출수 탁도, $\mathrm{DOC}$, 손실수두, 입자제거 특성에 미치는 영향 등을 분 석하였다. 응집제를 주입할 경우 유출수 탁도와 DOC 제거 효율는 향상되지만 손실수두가 증가하며, 입경 $2 \mu \mathrm{m}$ 보다 큰 입자까지 섬유볼 여재에서 제거 가능하여 입경이 $3 \sim 15 \mu \mathrm{m}$ 인 Cryptosporidium를 제거할 수 있다고 하였다. ${ }^{9)}$ Caliskaner 등은 섬유볼 여재는 큰 공극율과 압축 가능 특성으로 입상 여재보다 여과성능이 우수하다고 제시하였는데, 여재 입축비 를 $0 \sim 25 \%$ 까지 변화를 주어 유출수 탁도 효과를 분석하였 다. ${ }^{10)}$ Tsuneto 등은 하수처리장 2차 처리수를 부상식 고속 섬 유상 여재를 압축하여 여과조 상단에서 처리하고, 역세척은 여과조 전체 혼합방식을 적용하였다. 제시한 $\mathrm{SS}$ 제거효율은 $67 \sim 92 \%$ (평균 76\%), BOD 8 79\%(평균 32\%), COD 5 $14 \%$ (평균 $8.5 \%$ )이다. ${ }^{11)}$ Visvanathan 등은 이중 입상여재는 여과, 역세척과정 여재 간의 혼합문제가 발생하는데, 비중 차가 있는 비중 0.05 인 polypropylene (PP)과 비중 0.903인 
polyethylene (PE)재질 부상여재를 이용한 상향류 여과시 여 재 간의 혼합문제가 발생하지 않으며, 부상여재 입경이 작을 수록 응집된 플럭 제거효율이 높다고 제시하였다. ${ }^{12)}$ 양식장 순환수 처리를 위해 섬유사 여과를 적용결과 처리효율 범위 는 $\mathrm{COD}, \mathrm{SS}$, 탁도에 대해 각각 $38.7 \sim 69.2 \%, 26.7 \sim 45.6 \%$, $43.3 \sim 74.3 \%$ 라는 보고된 사례도 있다. ${ }^{13)}$ 여재 압축율을 증가 시키면 처리효율은 높아지지만 여과 압력은 기하급수적으로 증가하여 경제적이지 못함을 지적하고, 입자제거 효율 향상 을 위해서는 충진밀도보다 여과속도를 유입수 특성에 따라 적절히 조절이 효과적이라고 보고된 바 있다. ${ }^{14)}$ 입경 $5 \mathrm{~cm}$ 인 섬유볼 여재를 사용한 상향류식 여과장치로 $\mathrm{CSO}$ 처리를 분석 한 결과, 압축비를 높이면 공극이 감소하여 처리효율 증가한 다고 하였다. ${ }^{15)}$ 도시지역 초기우수를 처리하기 위해 PE재질 섬유볼 여재를 여과에 적용한 결과 손실 수두 값을 $10 \mathrm{~cm}$ 이하로 유지하기 위해서는 여과속도 $960 \mathrm{~m} / \mathrm{day}$ 이하, 압축비 $30 \%$ 이하를 제시한 보고도 있다. ${ }^{16)}$

본 연구에서는 도시지역 비점오염 미세입자를 제거하기 위 해 섬유볼 여재를 상향류식 2단 여과시스템에 적용하여 처리 특성을 분석하였다. 여과지 상단은 $15 \mathrm{~mm}$ 여재, 하단은 20 $\mathrm{mm}$ 여재를 카트리지에 충진하였고, 상단과 하단 중간에 역세 척 노즐을 추가하였다. 각 여재의 처리효율을 분석하여 하단 여재 처리효율 측정값으로 유출수 SS, 탁도 농도를 예측할 수 있는 식을 산정하였다. 여과 전, 여과 후, 역세척 후 여재 표면에 미세입자 부착특성 등을 확인하기 위해 주사전자현미 경사진(scanning electron microscope, SEM)을 측정하였다. 수면적 부하, 체류시간, 손실수두 등 운전조건에 따른 처리효 율의 변화 등을 분석하였다. 또한, 고형물질 물질수지를 분석 하여 역세척에 의한 여재 회복율을 분석하였다.

\section{2. 연구재료 및 방법}

\section{1. 섬유볼 여재 상향류 여과시스템 구성}

Fig.1과 같이 섬유볼 여재 상향류 여과시스템을 설계, 제작 하였다. 아크릴 재질 섬유볼 여재 여과시스템은 가로×세로는 $0.2 \mathrm{~m} \times 0.2 \mathrm{~m}$ 정방형으로 단면적 $0.04 \mathrm{~m}^{2}$ 이다. 하단여재 높 이 $0.3 \mathrm{~m}$, 중간 공간높이 $0.1 \mathrm{~m}$, 상단여재 높이 $0.3 \mathrm{~m}$, 여유고 는 $0.5 \mathrm{~m}$ 로 전체 높이는 $1.2 \mathrm{~m}$ 이다. 여재와 중간공간까지의 체적은 $28 \mathrm{~L}$ 이다. 여재 교체 및 칼럼 높이 조정, 운전조건, 유지관리 등을 고려하여 $0.3 \mathrm{~m}$ 단위로 카트리지 형태로 설 계·제작하였다. 역세척 효과를 높이기 위해 상단, 하단 여재 카트리지 중간에 높이 $0.1 \mathrm{~m}$ 공간을 두어 공기 역세척 노즐을 설치하였다. 하단 카트리지 하부에도 $0.1 \mathrm{~m}$ 공간에 공기 역세 척 노즐을 설치하였다. 상·하단 중간에는 폭 $10 \mathrm{~mm}$, 하단 카트리지 하부에는 폭 $30 \mathrm{~mm}$, 공경이 $1 \mathrm{~mm}$ 납작 노즐을 장 착하였다. 상-하단 여재의 처리특성을 분석하고자 중간 유출 수(Mid effluent) 시료 포트를 설치하였다. 여과 중 압력손실 변화를 측정하고자 상·하단 여재 카트리지에 $100 \mathrm{~mm}$ 간격으 로 압력계를 설치하였다. 여과지 상단은 $15 \mathrm{~mm}$, 하단은 20 $\mathrm{mm}$ 입경 섬유볼 여재를 각각 $15 \%$ 압축 충진하였다. 비점오 염처리시설 처리효율 인증을 위한 분말 입자를 $10 \%$ 농도로 조제하여 $20 \mathrm{~L}$ 교반 저류조에서 Masterflex 정량펌프로 수돗 물과 혼합하고 탁도 측정 후 유입수 탁도와 SS 농도를 조정할 수 있도록 하였다. 역세척 공기 컴프레셔 및 유량계를 설치하 여 공기량을 상-하단 카트리지 하부에 각각 조정할 수 있도록 하였다. 기타 바이패스 밸브, 핏팅, 배관, 유출수 저류조 등으 로 장치를 구성하였다.

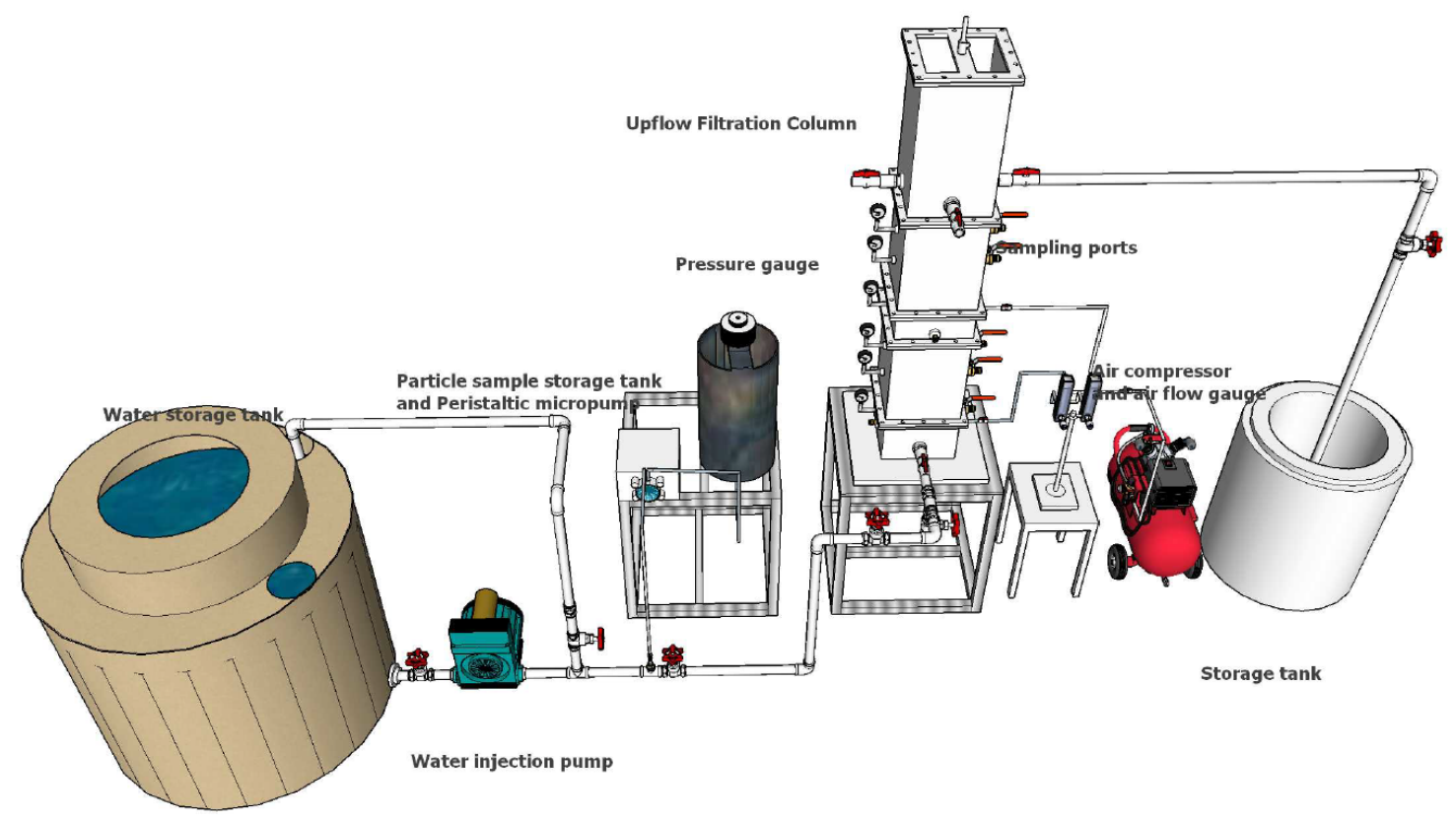

Fig. 1. Installation of fiber-ball media upflow filtration system. 


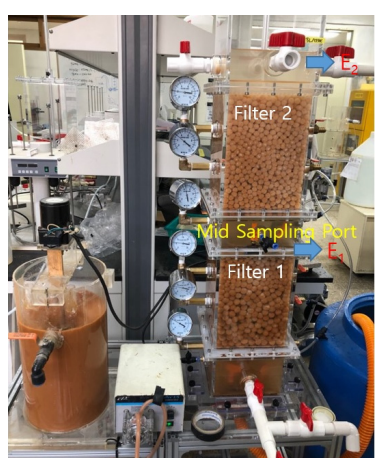

(a) Upflow column packing

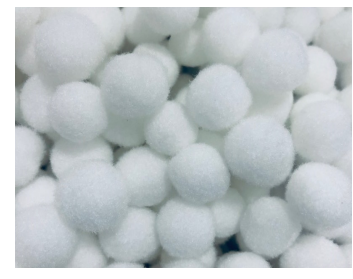

(b) Fiber-ball media

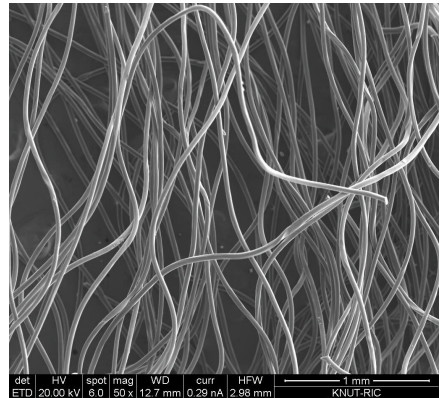

(c) SEM $\times 50$

Fig. 2. Fiber-ball media packing cartridge.

Fig.2는 여과칼럼에 $15 \mathrm{~mm}, 20 \mathrm{~mm}$ 섬유사볼 여재를 상·하 단에 각각 $300 \mathrm{~mm}$ 충진한 모습과 섬 여재의 단면을 $\mathrm{SEM}$ $\times 50$ 로 확대한 구조의 모습이다.

\section{2. 여재의 물리적 특성}

섬유볼 여재 물리적 특성으로, 형상은 구형, 입경은 15 $\mathrm{mm}, 20 \mathrm{~mm}$, 균등계수 1.1, 공극율 95\%의 polypropylene과 polyethylene를 혼합한 섬유이다. Polypropylene은 섬유 촉매 하에서 중합하여 만든 입체 규칙성 구조로 가볍고 마찰에 강하 며 굴곡 강도가 큰 내산- 내알칼리성 재질이다. Polyethylene은 열가소성 플라스틱의 하나로 가볍고 유연하며 포장용 필름, 섬유, 파이프, 전기절연체 등에 사용되는 재질이다. ${ }^{17)}$

정수위 투수시험기(동아시험기, DA-589) 섬유볼 여재를 $15 \%$ 압축 상태로 투수계수를 측정하였다. 7회 분석을 통해 산정한 $20 \mathrm{~mm}$ 여재의 평균투수계수는 $1.55 \mathrm{~cm} / \mathrm{sec}(55.8 \mathrm{~m} / \mathrm{hr})$ 로 분석 되었다. 여재 하나의 무게와 체적은 $15 \mathrm{~mm}$ 여재 $0.1663 \mathrm{~g}$, $1.802 \mathrm{~cm}^{3}$ 이며, $20 \mathrm{~mm}$ 여재 $0.3477 \mathrm{~g}, 4.187 \mathrm{~cm}^{3}$ 로 여재 밀도 는 각각 $0.0923 \mathrm{~g} / \mathrm{cm}^{3}, 0.0831 \mathrm{~g} / \mathrm{cm}^{3}$ 로 산정되었다.

\section{3. 처리시스템 운전 및 분석방법}

본 연구에 적용한 비점오염물질을 모의입자는 환경부 비점 오염처리시설 처리효율 인증을 위해 제공한 점토와 제올라이 트 혼합 입자를 사용하였다. 분말 입자는 $20 \mathrm{~L}$ 교반저류조에 서 $10 \%$ 농도로 조제 후 정량펌프로 유입수 관에 주입하여 SS 농도를 조절하였다. 수면적부하율(surface overflow rate, $\mathrm{SOR}), \mathrm{SS}$ 농도를 달리하여 총 5 회(5 Cycle) 운전하였고 총 운 전시간은 $375 \mathrm{~min}$ 이며 $5 \mathrm{~min}$ 간격으로 76개 시료를 채수하였 다. 운전 1 Cycle $\sim 3$ Cycle은 SOR를 평균 $20 \mathrm{~m}^{3} / \mathrm{m}^{2} / \mathrm{hr}$ 를 유지 하였으며 4 Cycle $~ 5$ Cycle 운전은 SOR을 최대 $32 \mathrm{~m}^{3} / \mathrm{m}^{2} / \mathrm{hr}$ 로 증가시켜 처리특성을 분석하였다. 유입수 처리조에 펌프 로 주입된 물은 분말 입자 교반류조에서 주입된 모의 입자와 혼합되어 상향류 여과 컬럼 하부로 주입하였다. 유입수 시료 와 유출수 시료는 1 단과 2 단 여재 카트리지에서 각각 $5 \mathrm{~min}$ 간격으로 채수하였다. 시료 채수와 동시에 여재 칼럼에 설치
된 6개의 압력계를 각각 측정하여 손실수두를 산정하였다. 운전 Cycle별 여과 종료 후 여과칼럼 정체수는 전량 하부로 배출하여 용량 및 시료를 채수하였다. 배수 후 저류조 물을 컬럼 상부로 주입하여 칼럼에 채운 후 에어 컴프레셔로 공기 를 주입하여 $5 \mathrm{~min}$ 간 1차 역세척 후 배수 및 시료채수하였다. 2차 역세척도 동일한 방법으로 $5 \mathrm{~min}$ 동안 실시하였다. 여재 내 잔류된 고형물질량 물질수지 산정하기 위해 1,2 차 역세척 후 배출량과 시료를 채수하였다. 채수된 시료는 탁도, SS, 그 리고 입경분포 등을 분석하였다. $\mathrm{SS}$ 는 시료 $500 \mathrm{~mL}$ 를 채수하 여 분석하였으며, 탁도는 Hach사 탁도계(측정범위 $0 \sim 4,000$ $\mathrm{NTU}$ )를 사용하였다. 입경은 입경분석기(particle size analyzer, SALD-2101, Schmadzu)를 이용하여 채수 시료별 평균입경, $10 \%, 60 \%, 90 \%$ 통과입경 $\left(\mathrm{D}_{\text {Mean, }} \mathrm{D}_{10 \%}, \mathrm{D}_{60 \%}, \mathrm{D}_{90 \%}\right)$ 등을 분석하였다. 상향류식 여과칼럼 5 Cycle 실험 후 섬유사 볼 여재의 운전 전·후와 역세척 후 매체 표면특성, 공극, 조직 치밀성 등을 관찰하기 위해 $50 \times, 100 \times, 200 \times$ 배율로 주사전 자현미경사진(SEM)을 측정하였다.

\section{3. 결과 및 고찰}

\section{1. 유입수 농도, 수면적부하율 변화에 따른 처리특성}

상단에는 $15 \mathrm{~mm}$ 섬유볼 여재를, 하단에는 $20 \mathrm{~mm}$ 섬유볼 여재를 충진하여 비점오염 모의입자에 대한 처리특성을 분석 하였다. Table 1에 운전 Cycle별 유량, SOR, 여과지 체류시간, 수두손실 등의 운전조건 및 유입수, 중간 유출수, 유출수 탁 도, SS농도, 처리효율 등에 대하여 요약 정리하였다. 1 Cycle $\sim 5$ Cycle까지 SOR은 $17.64 \sim 32.89 \mathrm{~m}^{3} / \mathrm{m}^{2} / \mathrm{hr}$ (평균 21.44 $\mathrm{m}^{3} / \mathrm{m}^{2} / \mathrm{hr}$ )로 운전하였으며 1 Cycle $\sim 3$ Cycle 동안에는 비점 오염 처리장치 운전기준인 $20 \mathrm{~m}^{3} / \mathrm{m}^{2} / \mathrm{hr}$ 수준을 유지하였다. 각 Cycle 운전 후에는 역세척을 실시하였다. 전체운전 동안 여과조 체류시간은 $1.28 \sim 2.38 \mathrm{~min}$ (평균 $1.99 \mathrm{~min}$ ), 수두손실 은 $6.22 \sim 8.19 \mathrm{~cm}$ (평균 $7.20 \mathrm{~cm}$ )를 나타내었다. 유입수 농도 는 SS농도 기준으로 1 Cycle은 고농도(평균 $716.7 \mathrm{mg} / \mathrm{L}$ ), 2 Cycle은 중농도(평균 $459.2 \mathrm{mg} / \mathrm{L}$ ), 3 Cycle은 저농도(평균 


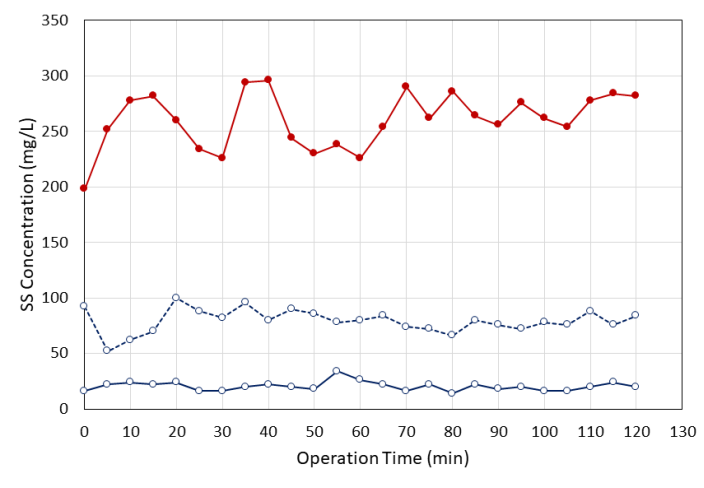

$\rightarrow$ Influent $\rightarrow-\infty$ Middle $\rightarrow \infty$ Effluent

(a) SS

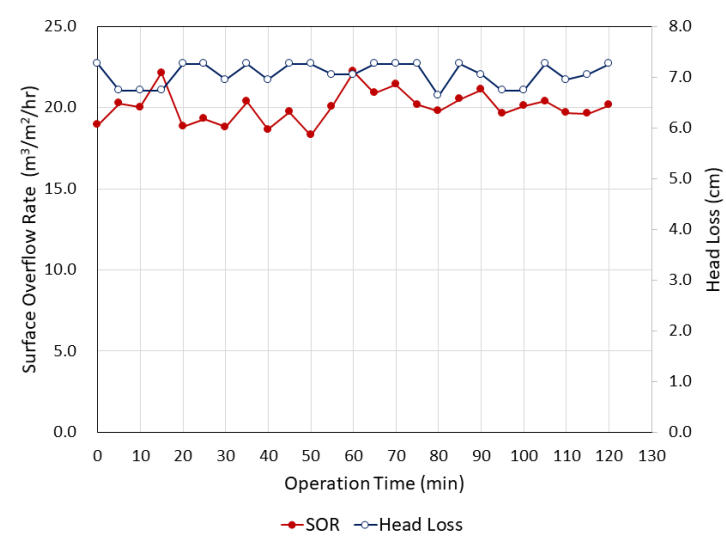

(c) SOR and head loss

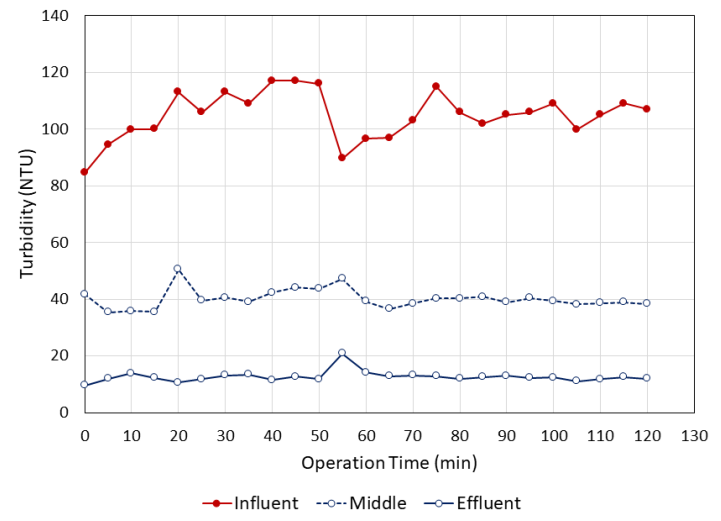

(b) Turbidity

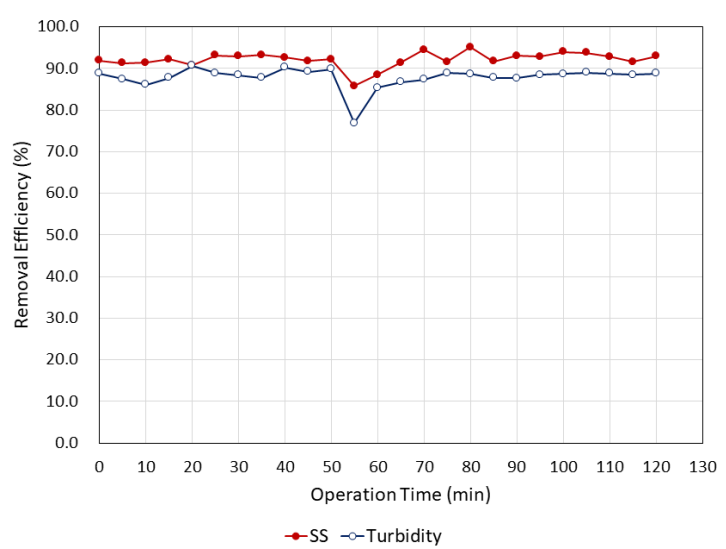

(d) Removal efficiency

Fig. 3. Variations of influent and effluent turbidity, SS removal efficiency and SOR with operation time for 3 cycle.

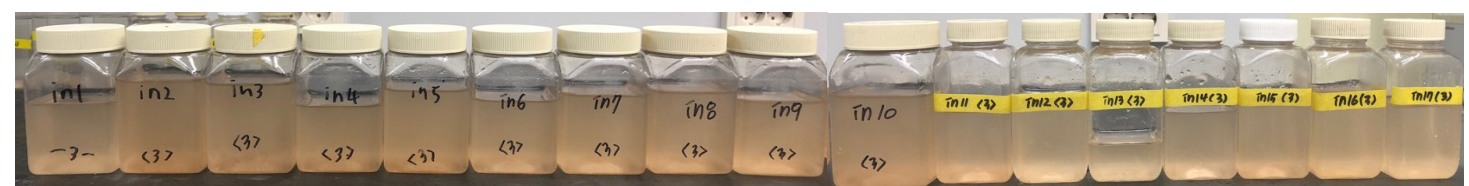

(a) Influent samples

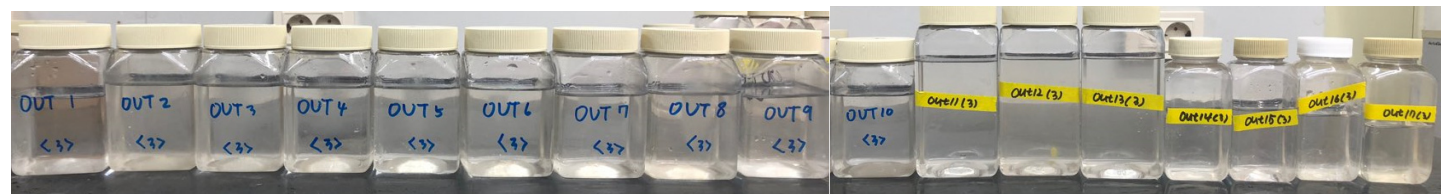

(b) Effluent samples

Fig. 4. Influent and effluent samples in case of 3 cycle operation.

$260.2 \mathrm{mg} / \mathrm{L}), 4$ 5 Cycle은 고농도 수준으로 유입시켰다. Fig.

3은 3 Cycle 운전 결과에 대한 유입수, 중간 유출수, 유출 수 농도의 변화, 처리효율, SOR과 수두손실을 나타낸 것이 다. 처리효율은 SS 85.7 95.1\%(평균 92.1\%), 탁도 76.7 $90.6 \%$ (평균 $87.8 \%$ )를 나타내었으며 유입수와 유출수 시료를 Fig. 4에 나타내었다.

Fig. 5는 1 5 Cycle까지 $375 \mathrm{~min}$ 운전기간 동안 $5 \mathrm{~min}$ 간 격 채수, 측정한 결과를 유입수, 중간유출수, 유출수 탁도, $\mathrm{SS}$ 농도변화를 나타낸 것이다. Table1에서와 같이 고농도 유입 수 조건 1 Cycle 운전 결과 유출수 탁도, SS농도 범위는 각각
$29.0 \sim 40.2 \mathrm{NTU}$ (평균 $34.3 \mathrm{NTU}$ ), $48.0 \sim 92.0 \mathrm{mg} / \mathrm{L}$ (평균 $62.7 \mathrm{mg} / \mathrm{L})$ 이다. 중농도 유입수 조건 2 Cycle 운전결과 유출 수 탁도, SS 농도 범위는 각각 $12.4 \sim 24.7 \mathrm{NTU}$ (평균 15.4 $\mathrm{NTU}$ ), $10.0 \sim 56.0 \mathrm{mg} / \mathrm{L}$ (평균 $24.7 \mathrm{mg} / \mathrm{L}$ )를 나타내었다. 저농 도 유입수 조건 3 Cycle 운전결과에서는 유출수 탁도, SS 농 도 범위는 각각 $9.5 \sim 20.8 \mathrm{NTU}$ (평균 $12.6 \mathrm{NTU}$ ), $14.0 \sim 34.0$ $\mathrm{mg} / \mathrm{L}$ (평균 $20.4 \mathrm{mg} / \mathrm{L}$ )으로 분석되었다. 유입수 $\mathrm{SS}$ 농도가 낮 을수록 유출수 탁도, $\mathrm{SS}$ 농도는 낮아지는 경향을 나타내었다. 여재 중간 유출수 농도의 변화도 유출수 농도와 유사한 경향 의 농도변화를 나타내었다. 유입수를 전처리 후 SS 농도를 
Table 1. Summary of the operation conditions, and the range of influent, mid effluent, effluent concentration, removal efficiency.

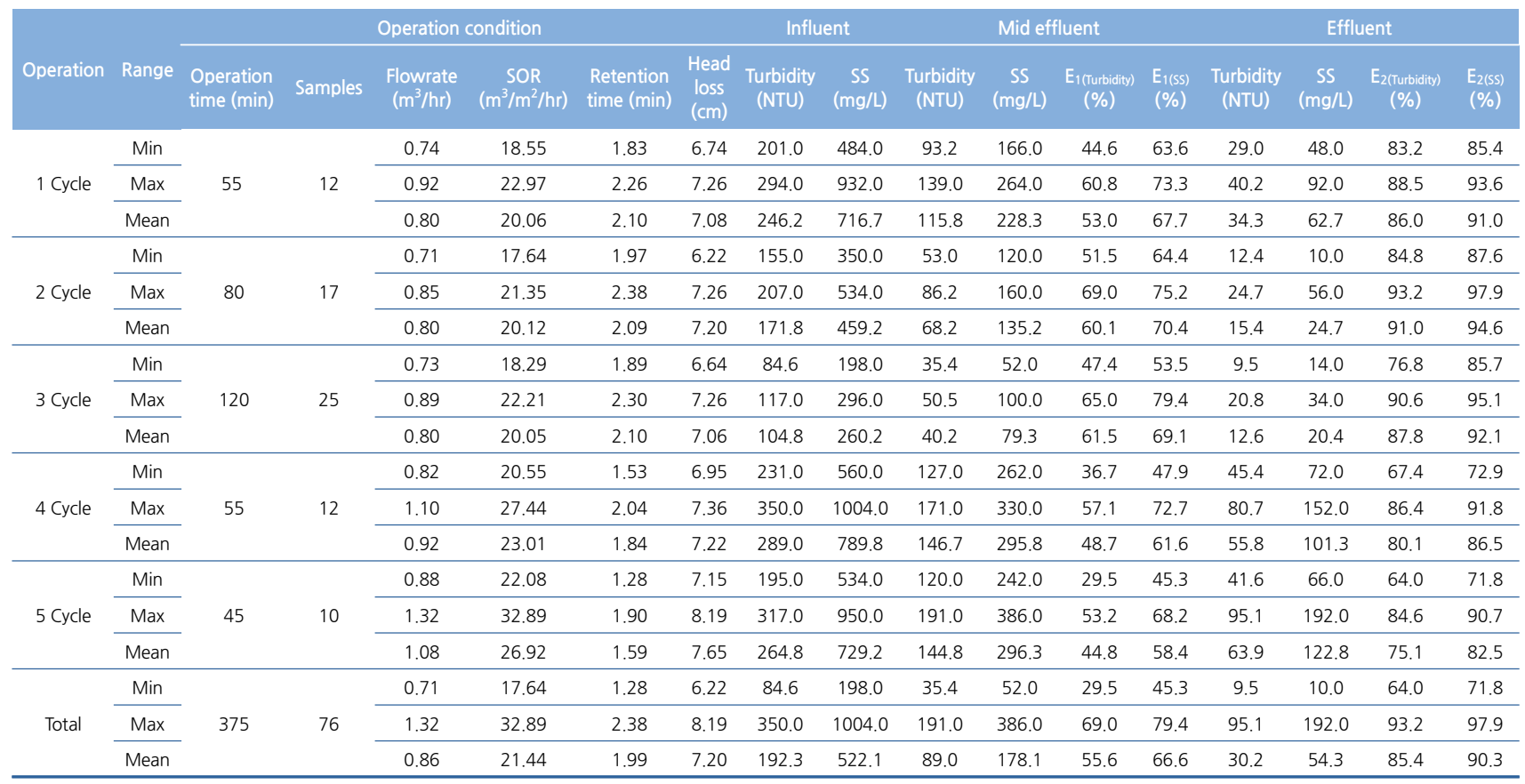

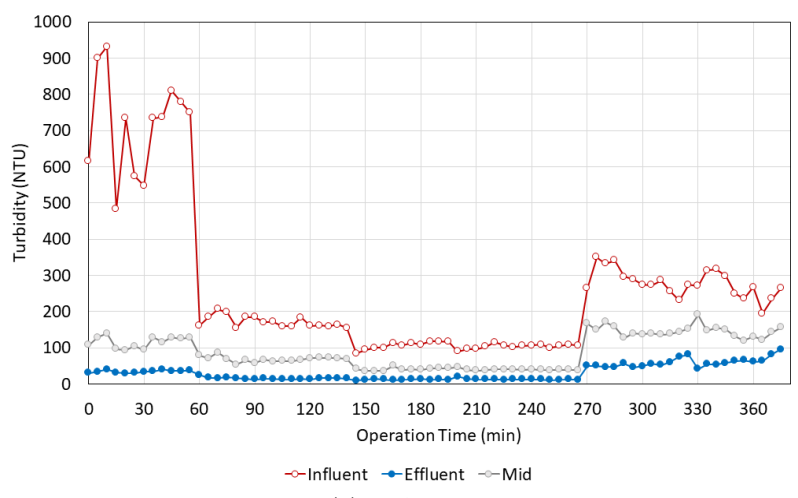

(a) Turbidity

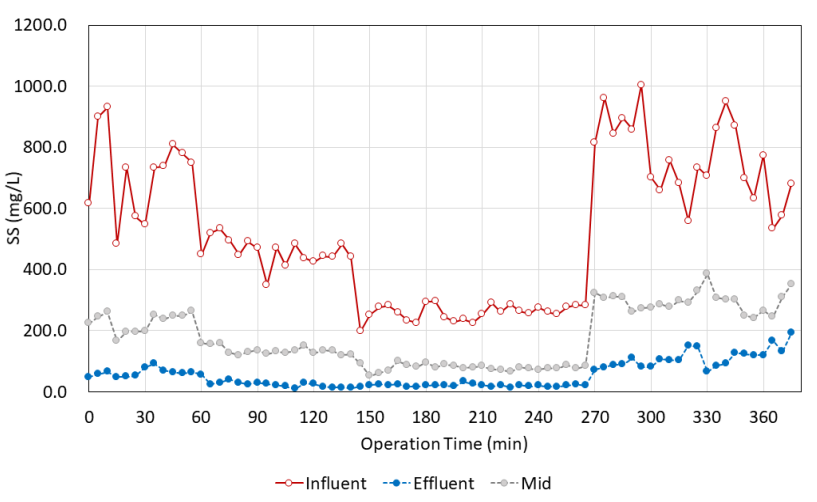

(b) SS)

Fig. 5. Variations of influent and effluent turbidity, SS concentration with operation time.

저감시킨 후 여과할 경우 낮은 유출수 농도로 처리가 가능할 것으로 판단된다. 고농도 유입수와 처리속도를 증가시킨 4 ,

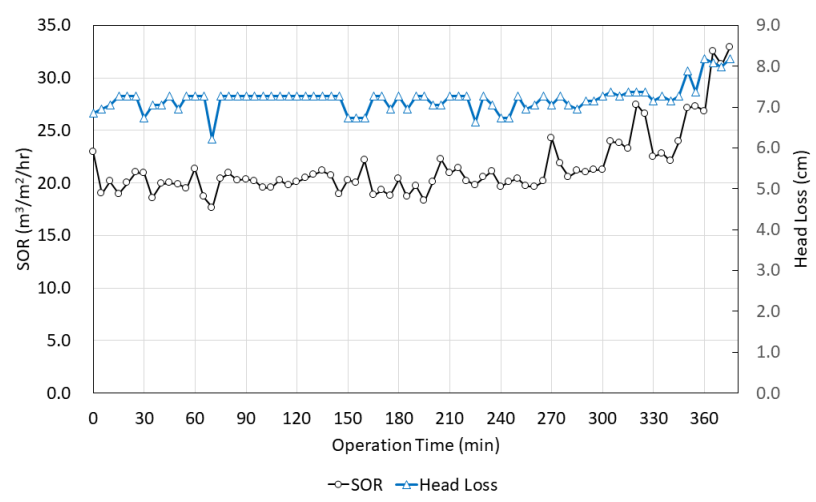

Fig.6. Variation of SOR and head loss with operation time.

5 Cycle 운전의 경우 유출수 탁도, SS 농도가 높아지는 경향 을 나타내고 있다.

운전시간에 대한 수면적부하율(SOR)과 수두손실의 변화를 Fig.6에 나타내었다. SOR $20 \mathrm{~m}^{3} / \mathrm{m}^{2} / \mathrm{hr}$ 수준으로 운전한 1 3 Cycle $255 \mathrm{~min}$ 까지는 수두손실의 변화는 $6.22 \sim 7.26 \mathrm{~cm}$ 로 일정하게 유지되었다. SOR을 $32.8 \mathrm{~m}^{3} / \mathrm{m}^{2} / \mathrm{hr}$ 까지 증가시켜 운 전한 4 5 Cycle에서는 수두손실이 $8.19 \mathrm{~cm}$ 까지 증가하였지 만 비점오염 여과시설 수두손실 $10 \mathrm{~cm}$ 기준 미만을 나타내었 다. Fig. 7은 여재 누적 단위 면적당 고형물 부하량 $\left(\mathrm{kg} / \mathrm{m}^{2}\right)$ 은 고농도 운전, SOR 증가한 4 5 Cycle 운전에서 증가하는 추 세를 나타내었다. 단위 면적당 고형물 부하량과 $\mathrm{SS}$ 제거효율 과의 관계는 Fig.8에서와 같이 상관계수 0.34로 반비례 관계 를 나타내었다. 


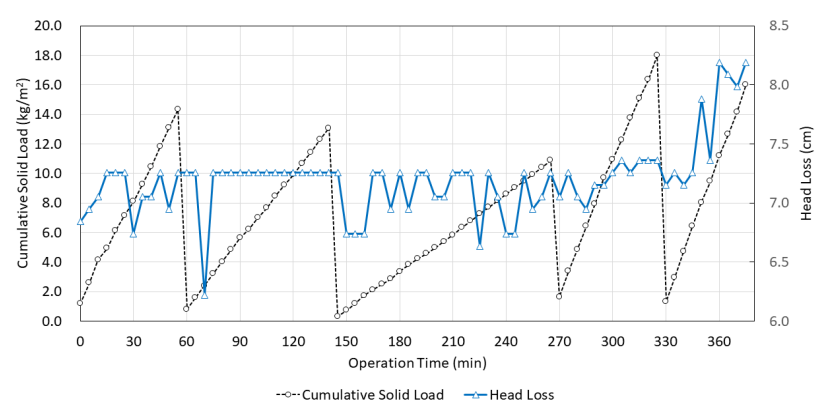

Fig. 7. Variation of solids unit loading and head loss with operation time.

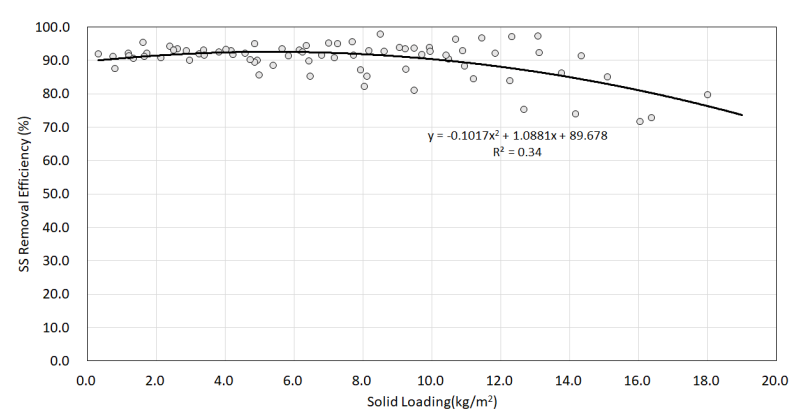

Fig. 8. Relationship between solid loading and SS removal efficiency.

\section{2. 운전조건별 처리효율 특성분석}

운전시간에 대한 유입수, 중간 유출수, 유출수의 탁도와 SS 제거효율 변화를 Fig. 9에 나타내었다. 1 3 Cycle 운전 시 유출수 처리효율 범위는 탁도 $76.8 ~ 93.2 \%$ (평균 88.3\%), SS $85.4 \sim 97.9 \%$ (평균 92.7\%)로 분석되었다. SOR를 증가시킨 $4 \sim 5$ Cycle 운전 시에 유출수 처리효율 범위는 탁도 64.0 86.4\%(평균 77.6\%), SS $71.8 \sim 91.8 \%$ (평균 84.5\%)를 나타내 었다. $1 \sim 5$ Cycle 운전에서 중간유출수에 대해 처리효율의 범 위는 탁도 $29.5 \sim 69.0 \%$ (평균 55.6\%), SS $45.3 \sim 79.4 \%$ (평균 $66.6 \%$ )를 나타내었다. 상향류 여과 $300 \mathrm{~mm}$ 높이의 1단 여재 카트리지에서 제거량은 $\mathrm{SS}$ 기준으로 평균 $66.6 \%$ 처리하는 것 으로 분석되었다.

탁도는 측정이 용이하고, 연속적인 모니터링이 가능하므로 탁도와 SS 제거효율 관계를 분석하여 운전조건을 분석하는데 활용될 수 있다. Fig. 10 은 유출수 탁도 제거효율, $\mathrm{E}_{\text {(Turbidity) }} \%$ 과 $\mathrm{SS}$ 제거효율, $\mathrm{E}_{(\mathrm{SS})} \%$ 의 상관관계로 식 (1)과 같이 상관계수 $\left(\mathrm{R}^{2}\right)$ 는 0.90 으로 높게 나타내었다.

$$
\mathrm{E}_{(\mathrm{SS})}=0.78 \mathrm{E}_{(\text {Turbidity) }}+23.7
$$

수두손실 변화와 탁도, SS 제거효율과는 Fig. 11과 같이 반비례 관계를 나타내며 상관계수는 $0.31 \sim 0.33$ 값을 나타 내었다.

SOR 변화와 탁도, SS 제거효율과는 음의 상관관계로 Fig. 12와 같다. SOR $28 \mathrm{~m}^{3} / \mathrm{m}^{2} / \mathrm{hr}\left(=672 \mathrm{~m}^{3} / \mathrm{m}^{2} / \mathrm{day}\right)$ 까지의 조건에

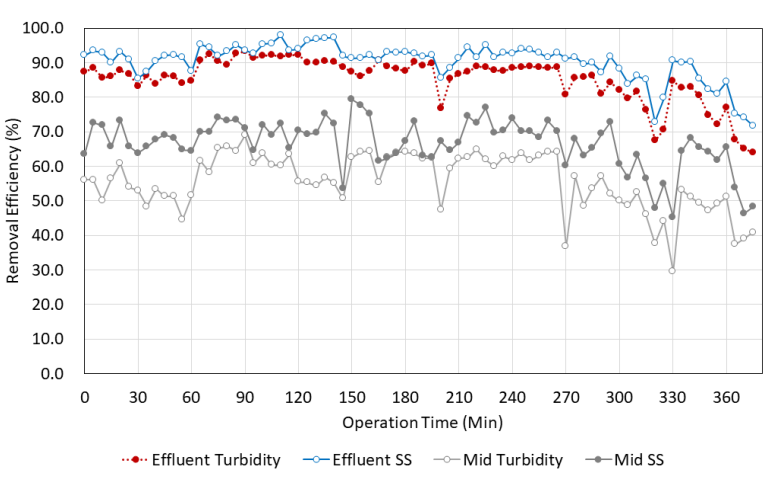

Fig. 9. Variations of removal efficiency of turbidity, SS for effluent and mid effluent.

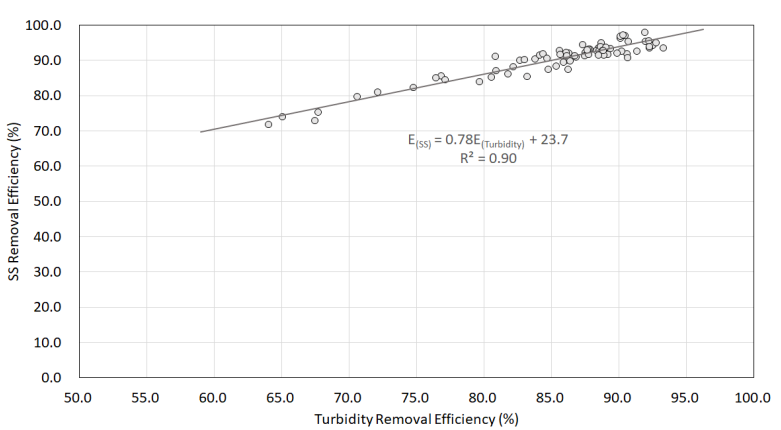

Fig. 10. Relationship between SS and turbidity removal efficiency.

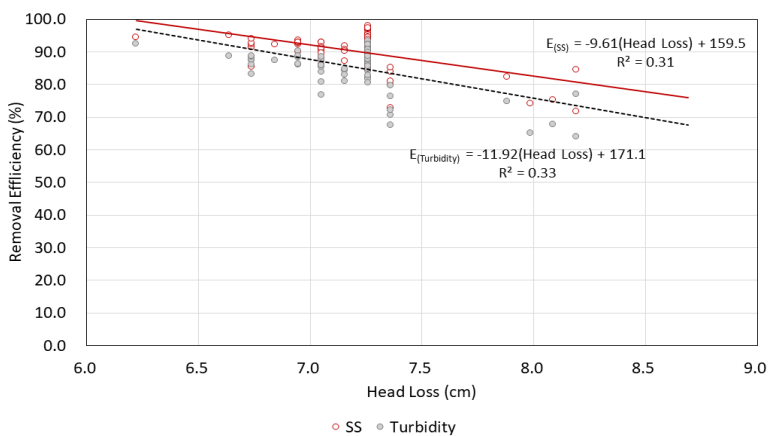

Fig. 11. Relationship between head loss and removal efficiency.

서 SS $80 \%$ 이상이 가능한 것으로 분석되었다. SOR과 탁도 및 SS 제거효율과 상관관계식은 식 (2), (3)과 같고 상관계수 는 각각 $0.79,0.72$ 로 분석되었다.

$$
\begin{aligned}
& \mathrm{E}_{(\mathrm{SS})}=-1.51(\mathrm{SOR})+122.7 \\
& \mathrm{E}_{(\text {Turbidity })}=-1.92(\mathrm{SOR})+126.5
\end{aligned}
$$

여과칼럼내 수리학적 체류시간(min)과 탁도, SS 제거효율과 는 양의 상관관계로 Fig. 13 과 같다. 제거효율 $80 \%$ 이상을 유지 하기 위한 체류시간은 SS $1.45 \mathrm{~min}$, 탁도 $1.79 \mathrm{~min}$ 으로 분석되 었다. 체류시간과 탁도 및 SS 제거효율과 상관관계식은 식 (4), (5)와 같고 상관계수는 각각 $0.76,0.66$ 을 나타내었다.

$$
\mathrm{E}_{\text {(Turbidity) }}=25.11(\text { Retention Time })+35.38
$$




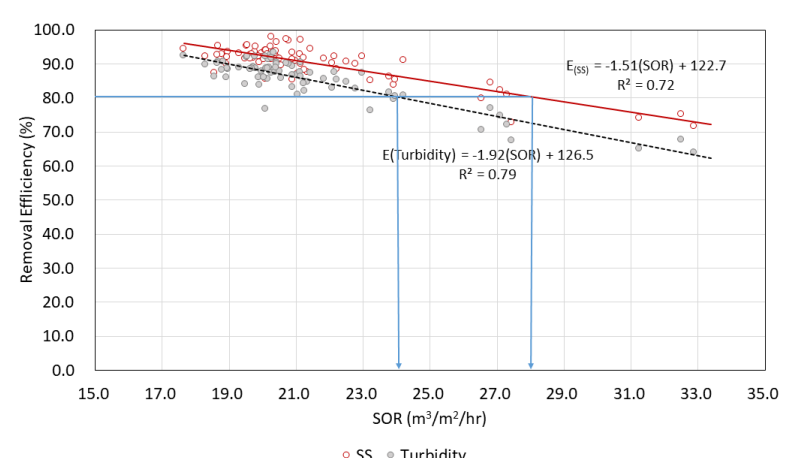

Fig. 12. Relationship between SOR and removal efficiency.

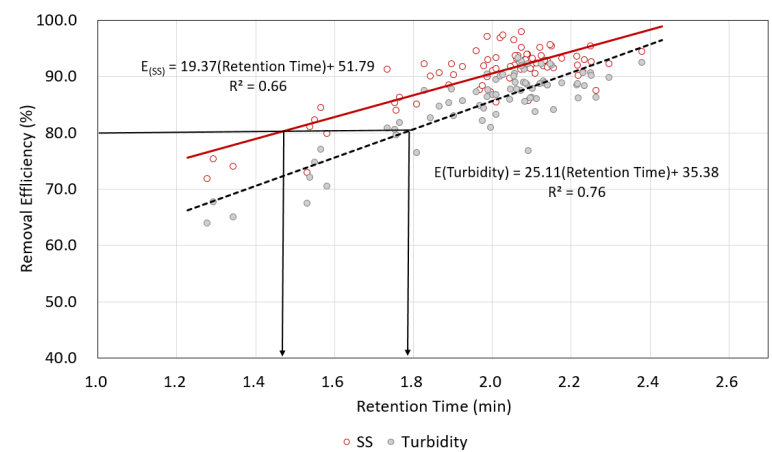

Fig. 13. Relationship between retention time and removal efficiency.

$$
\mathrm{E}_{(\mathrm{SS})}=19.37(\text { Retention Time })+51.79
$$

\section{3. 중간 유출수 수질과 유출수 수질}

상단과 하단 중간에 $100 \mathrm{~mm}$ 공간을 설치하여 공기 역세척 노즐을 설치하였고, 하단 여재 통과한 시료를 채수하여 처리 효율 분석을 시도하였다. Fig. 2에서와 같이 하단여재(Filter 1) 시료 채수시점에 해당하는 처리효율을 $\mathrm{E}_{1}(\%)$, 상단여재 (Filter 2)를 통과한 탁도(NTU), SS (mg/L) 값을 C로 하였을 때 다음 식 (6)을 적용하였다.

$$
\mathrm{C}=\mathrm{C}_{\mathrm{o}}\left(1-\mathrm{E}_{1}\right)^{2}
$$

여기서, $\mathrm{E}_{1}$ 은 하단 여재 처리효율(\%), $\mathrm{C}_{0}$ 는 유입수 SS (mg/L), Turbidity (NTU), C는 유출수 SS (mg/L), Turbidity (NTU)이다. 식 (6)을 적용하여 운전시간별 유출수 탁도와 SS 를 예측한 값을 Fig. 14에 나타내었다. 탁도의 측정값과 예측 값의 범위는 각각 $9.5 \sim 95.1 \mathrm{NTU}$ (평균 $30.2 \mathrm{NTU}$ ), 12.6 $134.6 \mathrm{NTU}$ (평균 $30.2 \mathrm{NTU}$ )로 나타내었다. 또한, $\mathrm{SS}$ 의 측정 값과 예측값의 범위는 각각 $10.0 \sim 192.0 \mathrm{mg} / \mathrm{L}$ (평균 54,3 $\mathrm{mg} / \mathrm{L}$ ), $10.7 \sim 211.0 \mathrm{mg} / \mathrm{L}$ (평균 $63.4 \mathrm{mg} / \mathrm{L}$ )로 탁도와 $\mathrm{SS}$ 농도 모두 예측값이 실측값보다 다소 높게 산정되었다. 탁도, SS와 실측값과 예측값의 관계는 Fig. 15와 같으며 상관계수는 각각 $0.76,0.74$ 로 분석되었다.

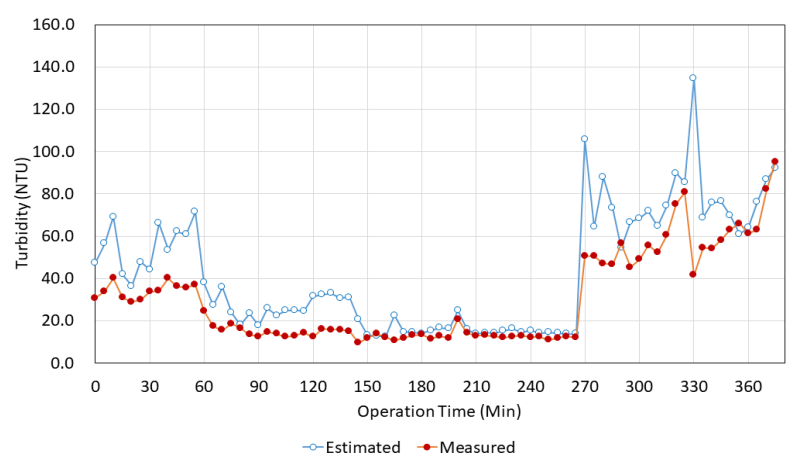

(a) Turbidity

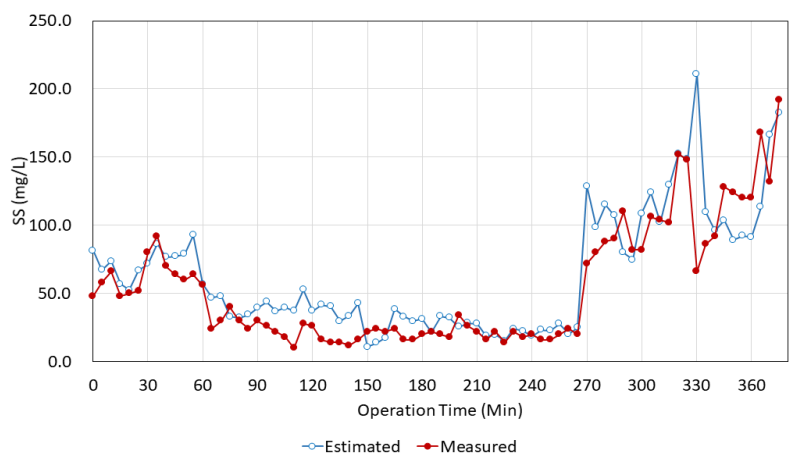

(b) SS

Fig. 14. Measured and estimated effluent turbidity, SS with operation time.

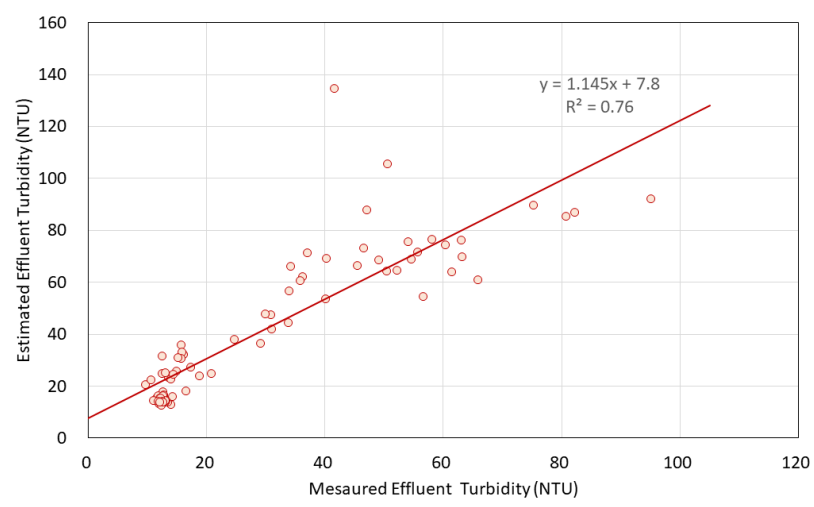

(a) Turbidity

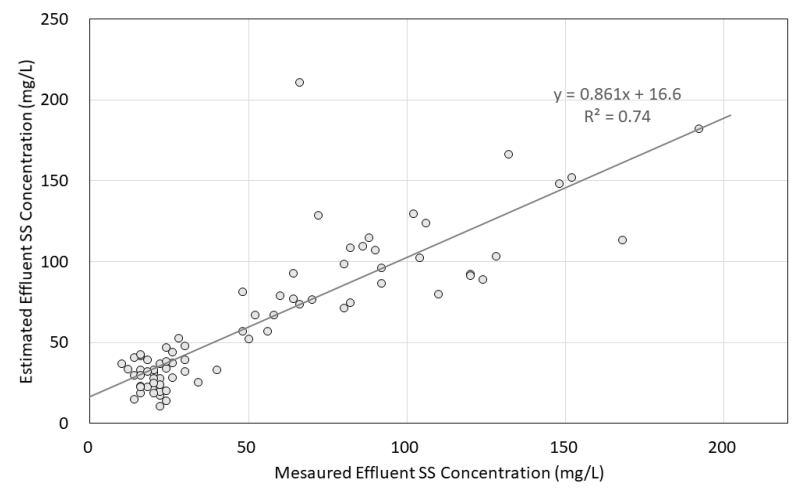

(b) $\mathrm{SS}$

Fig. 15. Relationship between measured and estimated value for effluent. 


\section{4. 입경분포 및 SEM 측정결과}

유입수, 중간 유출수, 유출수 시료 입경 및 입경분포 특성을 분석하였다. Shimadzu SALD 2101 프로그램을 이용하여 입 자 수는 부피를 기준하였고, 입경은 $0.01 \sim 1000 \mu \mathrm{m}$ 까지 0 $\sim 100 \%$ 누적입경분포를 산정하였다. 입경분석 시료 수는 유
입수, 중간 유출수, 유출수 시료 각각 76 개와 역세척 배출수 시료 15 개로 총 243 개 자료를 분석한 결과이다. 각 여재별 유입수와 유출수의 누적 입경분포를 분석한 결과 중앙입경 $\left(\mathrm{D}_{\text {Median }}\right)$, 최빈입경 $\left(\mathrm{D}_{\text {Modal }}\right)$, 평균입경 $\left(\mathrm{D}_{\text {Mean }}\right), 10 \%$ 입경 $\left(\mathrm{D}_{10}\right)$, $60 \%$ 입경 $\left(\mathrm{D}_{60}\right), 90 \%$ 입경 $\left(\mathrm{D}_{90}\right)$ 을 Table 2에 요약하였다. 유입

Table 2. Summary of particle size distribution analysis.

\begin{tabular}{|c|c|c|c|c|c|c|c|c|c|}
\hline Sample & Operation & Range & $\begin{array}{l}\text { DMedian } \\
\text { (um) }\end{array}$ & $\begin{array}{l}\text { D Modal } \\
(\mu \mathrm{m})\end{array}$ & $\begin{array}{l}D_{\text {Mean }} \\
(\mu \mathrm{m})\end{array}$ & $\begin{array}{c}\text { Stand } \\
\text { deviation }(\mu \mathrm{m})\end{array}$ & $\begin{array}{l}D_{10 \%} \\
(\mu \mathrm{m})\end{array}$ & $\begin{array}{l}D_{60 \%} \\
(\mu m)\end{array}$ & $\begin{array}{l}D_{90 \%} \\
(\mu \mathrm{m})\end{array}$ \\
\hline \multirow{15}{*}{ Influent } & \multirow{3}{*}{1 Cycle } & Min & 0.48 & 0.45 & 0.52 & 0.15 & 0.36 & 0.52 & 0.71 \\
\hline & & Max & 1.40 & 1.41 & 1.50 & 0.24 & 1.08 & 1.47 & 1.96 \\
\hline & & Mean & 0.70 & 0.68 & 0.76 & 0.17 & 0.54 & 0.75 & 1.12 \\
\hline & \multirow{3}{*}{2 Cycle } & Min & 0.48 & 0.45 & 0.52 & 0.10 & 0.35 & 0.51 & 0.72 \\
\hline & & Max & 2.21 & 2.24 & 2.23 & 0.24 & 1.67 & 2.33 & 2.95 \\
\hline & & Mean & 0.72 & 0.71 & 0.79 & 0.19 & 0.55 & 0.77 & 1.26 \\
\hline & \multirow{3}{*}{3 Cycle } & Min & 0.48 & 0.45 & 0.54 & 0.19 & 0.36 & 0.51 & 1.00 \\
\hline & & Max & 0.63 & 0.56 & 0.72 & 0.24 & 0.43 & 0.74 & 1.44 \\
\hline & & Mean & 0.58 & 0.53 & 0.65 & 0.21 & 0.41 & 0.64 & 1.29 \\
\hline & \multirow{3}{*}{4 Cycle } & Min & 0.48 & 0.45 & 0.55 & 0.20 & 0.35 & 0.52 & 1.04 \\
\hline & & Max & 0.62 & 0.56 & 0.71 & 0.26 & 0.42 & 0.72 & 1.48 \\
\hline & & Mean & 0.55 & 0.47 & 0.64 & 0.24 & 0.38 & 0.62 & 1.34 \\
\hline & \multirow{3}{*}{5 Cycle } & Min & 0.48 & 0.45 & 0.54 & 0.18 & 0.35 & 0.51 & 0.85 \\
\hline & & Max & 0.57 & 0.45 & 0.69 & 0.26 & 0.37 & 0.68 & 1.52 \\
\hline & & Mean & 0.50 & 0.45 & 0.57 & 0.21 & 0.36 & 0.55 & 1.08 \\
\hline \multirow{15}{*}{ Mid effluent } & \multirow{3}{*}{1 Cycle } & Min & 0.50 & 0.45 & 0.63 & 0.21 & 0.35 & 0.60 & 1.25 \\
\hline & & Max & 0.71 & 0.71 & 0.81 & 0.27 & 0.45 & 0.81 & 1.63 \\
\hline & & Mean & 0.62 & 0.57 & 0.71 & 0.24 & 0.41 & 0.69 & 1.48 \\
\hline & \multirow{3}{*}{2 Cycle } & Min & 0.54 & 0.56 & 0.59 & 0.19 & 0.41 & 0.58 & 0.91 \\
\hline & & Max & 1.11 & 1.12 & 1.16 & 0.25 & 0.55 & 1.23 & 2.53 \\
\hline & & Mean & 0.60 & 0.60 & 0.67 & 0.21 & 0.43 & 0.64 & 1.29 \\
\hline & \multirow{3}{*}{3 Cycle } & Min & 0.47 & 0.45 & 0.50 & 0.11 & 0.35 & 0.50 & 0.66 \\
\hline & & Max & 0.54 & 0.45 & 0.64 & 0.26 & 0.40 & 0.59 & 1.47 \\
\hline & & Mean & 0.50 & 0.45 & 0.57 & 0.20 & 0.37 & 0.55 & 1.11 \\
\hline & \multirow{3}{*}{4 Cycle } & Min & 0.58 & 0.56 & 0.65 & 0.21 & 0.42 & 0.62 & 1.28 \\
\hline & & Max & 0.60 & 0.56 & 0.70 & 0.23 & 0.43 & 0.67 & 1.44 \\
\hline & & Mean & 0.59 & 0.56 & 0.67 & 0.22 & 0.42 & 0.64 & 1.36 \\
\hline & \multirow{3}{*}{5 Cycle } & Min & 0.58 & 0.45 & 0.65 & 0.21 & 0.41 & 0.62 & 1.28 \\
\hline & & Max & 0.76 & 0.56 & 0.81 & 0.25 & 0.44 & 0.90 & 1.56 \\
\hline & & Mean & 0.62 & 0.55 & 0.71 & 0.22 & 0.42 & 0.70 & 1.42 \\
\hline \multirow{15}{*}{ Effluent } & \multirow{3}{*}{1 Cycle } & Min & 0.54 & 0.56 & 0.59 & 0.18 & 0.41 & 0.58 & 0.90 \\
\hline & & Max & 0.56 & 0.56 & 0.63 & 0.21 & 0.42 & 0.59 & 1.31 \\
\hline & & Mean & 0.55 & 0.56 & 0.60 & 0.19 & 0.41 & 0.58 & 1.05 \\
\hline & \multirow{3}{*}{2 Cycle } & Min & 0.08 & 0.09 & 0.08 & 0.05 & 0.06 & 0.09 & 0.11 \\
\hline & & Max & 3.06 & 2.82 & 3.11 & 0.30 & 2.61 & 3.20 & 3.97 \\
\hline & & Mean & 1.17 & 1.10 & 1.29 & 0.15 & 0.98 & 1.26 & 2.00 \\
\hline & \multirow{3}{*}{3 Cycle } & Min & 0.08 & 0.09 & 0.08 & 0.09 & 0.06 & 0.09 & 0.11 \\
\hline & & Max & 0.68 & 0.71 & 0.87 & 0.27 & 0.53 & 0.73 & 2.62 \\
\hline & & Mean & 0.67 & 0.62 & 0.73 & 0.17 & 0.53 & 0.71 & 1.23 \\
\hline & \multirow{3}{*}{4 Cycle } & Min & 0.56 & 0.56 & 0.62 & 0.19 & 0.42 & 0.60 & 0.96 \\
\hline & & Max & 1.21 & 1.12 & 1.24 & 0.30 & 0.49 & 1.35 & 3.29 \\
\hline & & Mean & 0.66 & 0.61 & 0.74 & 0.23 & 0.43 & 0.73 & 1.63 \\
\hline & \multirow{3}{*}{5 Cycle } & Min & 0.53 & 0.36 & 0.65 & 0.18 & 0.32 & 0.66 & 1.34 \\
\hline & & Max & 1.12 & 1.12 & 1.23 & 0.28 & 0.81 & 1.21 & 2.28 \\
\hline & & Mean & 0.82 & 0.81 & 0.86 & 0.24 & 0.47 & 0.94 & 1.67 \\
\hline
\end{tabular}



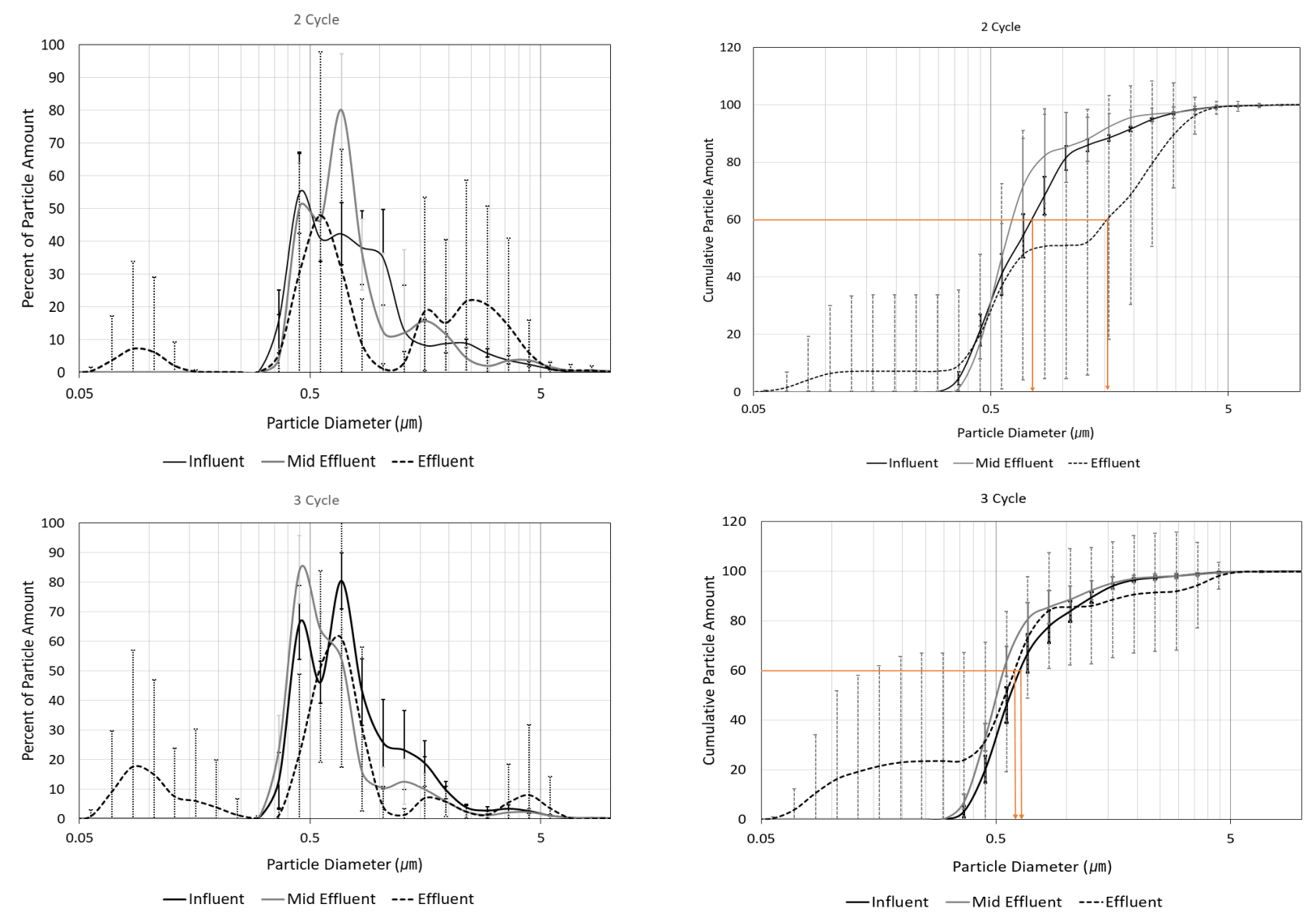

Fig. 16. Particle size distributions for influent, mid effluent and effluent. Each of influent and effluent data set is mean PSDs and standard deviation.

수 평균입경 $\mathrm{D}_{\text {Mean }}$ 범위는 $0.52 \sim 2.23 \mu \mathrm{m}$ (평균 $0.67 \mu \mathrm{m}$ )이고, 중간 유출수는 $0.65 \sim 1.16 \mu \mathrm{m}$ (평균 $0.79 \mu \mathrm{m}$ ), 유출수는 0.59 $\sim 3.11 \mu \mathrm{m}$ (평균 $0.59 \mu \mathrm{m}$ )로 분석되었다. 유입수와 비교하여 유출수 평균입경은 다소 감소하는 결과를 나타내었지만 큰 차이점은 없는 것으로 판단된다. 2 Cycle, 3 Cycle 운전에서 유입수, 중간 유출수, 유출수의 입경분포와 누적입경분포를 표준편차와 같이 Fig. 16에 나타내었다. $0.5 \mu \mathrm{m}$ 전후 입경이 가장 많이 분포하고 있고, 유출수 표준편차는 $0.1 \mu \mathrm{m}$ 범위와 $2.0 \sim 3.0 \mu \mathrm{m}$ 범위에서 높게 나타나고 있다. 여과 후 입경은 감소하지만 $60 \%$ 누적입경분포 표준편차가 증가하는 경향이 있는데, 3 Cycle 누적입경분포의 경우에서도 유출수 입경증 가와 $0.1 \mu \mathrm{m}$ 부근 표준편차가 증가하는 경향을 나타내고 있 다. 이는 여과과정에서 여재 내 포획되어 입경이 감소하는 경향과 여재 공극 내에서 입자 간 충돌, 흡착 등으로 입자 간에 결합이 발생하여 유입수 입경보다 큰 유출수 입경분포 가 나타나는 것으로 판단된다. 입경분포 변화 해석은 향후 다양한 운전조건에 따른 분석이 필요할 것으로 사료된다.

Fig. 17은 여과 중, 여과 후, 역세척 후 여재 모습을 50,100 , 200 배율로 SEM 촬영한 것이다. 여과전 섬유볼 여재에 입자 가 없는 것을 보여주며, 여과 후에는 다양한 입경을 가진 입 자들이 여재에 축적되어 있는 것으로 확인할 수 있다. 역세척
후 매우 미세한 입자들이 섬유사에 부착되어 제거하기 어려 운 고형물 잔량으로 판단된다.

\section{5. 역세척 효과 분석}

도시지역 강우 초기유출수 농도는 유역특성에 따라 다르지 만 대체로 SS 기준으로 $200 \sim 1,000 \mathrm{mg} / \mathrm{L}$ 의 범위를 가진 고 농도이므로 여재 막힘에 따른 처리효율 감소 발생시간이 매 우 짧아질 수 있다. 여과형 비점오염 처리시설은 고농도의 초기유출수를 처리했을 경우 미세 고형물질과 흡착된 오염 물질들이 여재 내 축적되어 다음 강우 시 여재에서 돌파되 어 배출된다. ${ }^{3)}$ 여과형 비점오염 처리시설에서 역세척은 성 능을 회복시키는 주요한 공정이다. ${ }^{18)} 1$ Cycle $~ 5$ Cycle 운전 시간 동안 총 5 회의 역세척 결과에 대한 여재 회복율을 분석 하였다. 여과 후 여과컬럼 잔류수를 전량 배수 후 공기 주입 속도 $15 \mathrm{~m}^{3} / \mathrm{m}^{2} / \mathrm{hr}$ 로 여재중간 공간과 하부 여재에 주입하였 다. Visvanathan 등은 공기 주입속도를 $100 \mathrm{~m}^{3} / \mathrm{m}^{2} / \mathrm{hr}$ 로 $2 \mathrm{~min}$, $50 \mathrm{~m}^{3} / \mathrm{m}^{2} / \mathrm{hr}$ 로 $3 \mathrm{~min}$ 동안 여재를 $65 \%$ 팽창시켜 역세척을 실 시하였다. ${ }^{12)}$ 여과형 비점오염저감시설 설계기준은 공기 주입 속도를 $50 \mathrm{~m} / \mathrm{hr}$ 를 권장하고 있다. ${ }^{18)}$ 본 연구에서는 역세척 공기 주입속도 $15 \mathrm{~m}^{3} / \mathrm{m}^{2} / \mathrm{hr}$ 로 하여 기타 연구사례의 $1 / 3$ 미만 을 적용하여 경제성 부분을 고려하였다. 여과칼럼 잔류수를 


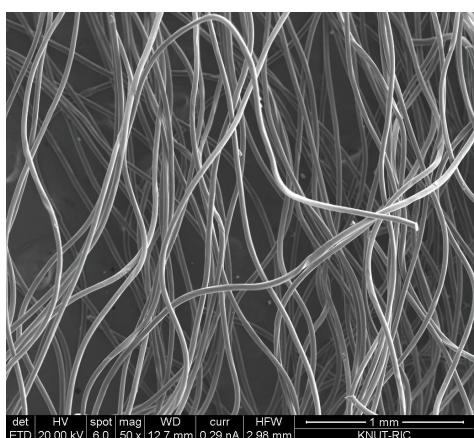

$50 x$

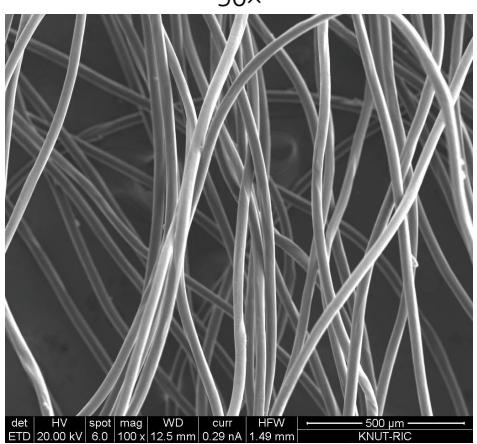

$100 \times$

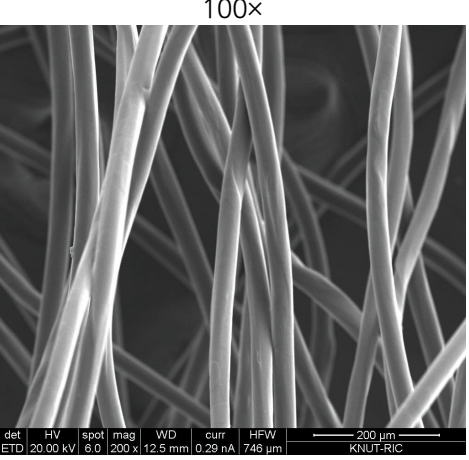

$200 x$

(a) Before filtration

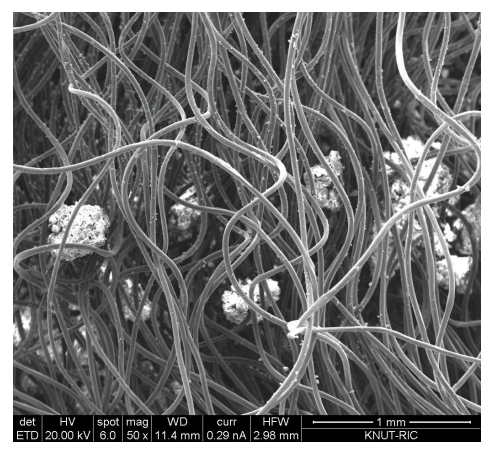

$50 \times$

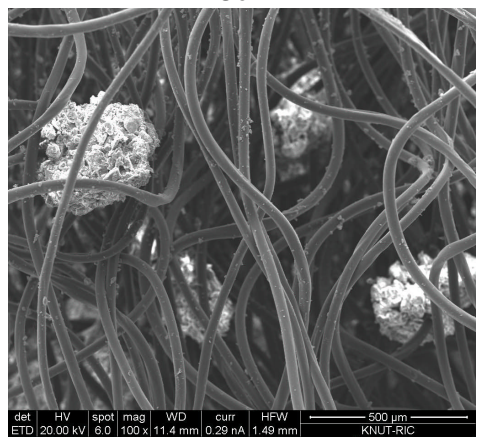

$100 \times$

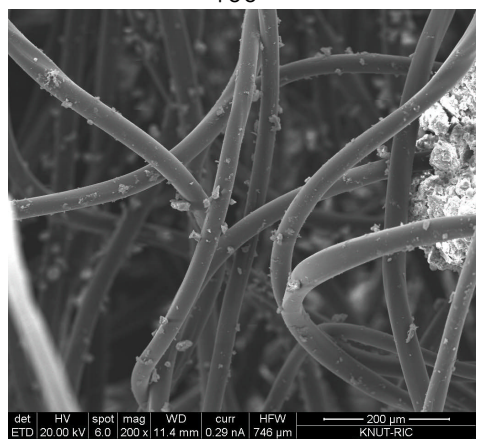

$200 x$

(b) After filtration

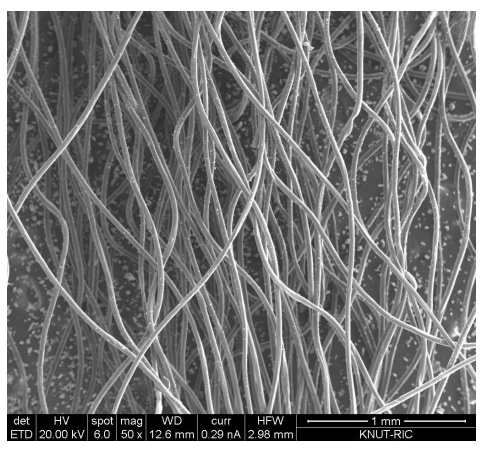

$50 \times$

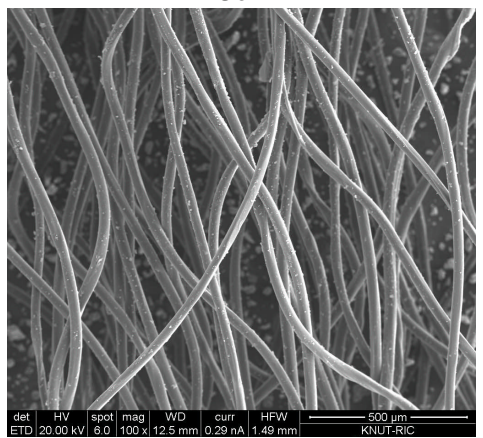

$100 \times$

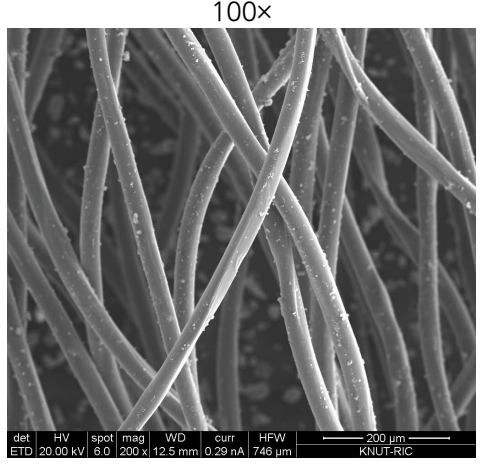

$200 x$

(c) After backwashing

Fig. 17. SEM images of fiber ball media before, after filtration and after backwashing.

배출 후 수돗물을 역과 칼럼에 채운 후 역세척 공기 주입속도 $15 \mathrm{~m}^{3} / \mathrm{m}^{2} / \mathrm{hr}$ 로 5 분 동안 1 차 역세척을 실시하였다. 1 차 역세 척 후 전량 배수 후 수돗물을 역과 칼럼에 채운 후 역세척 공기 주입속도 $15 \mathrm{~m}^{3} / \mathrm{m}^{2} / \mathrm{hr}$ 로 5 분 동안 2차 역세척을 실시하 였다. 여과 후 여과칼럼에 잔류수, 1 차, 2 차 역세척 후 배수된 역세척 수량 $(\mathrm{L})$ 를 측정하였고 배수된 역세척 수의 $\mathrm{SS}$ 농도를 측정하였다. 역세척에 의한 여재 여과 회복력을 분석하기 위 해 칼럼여과장치에 대한 고형물 물질수지 Fig. 18과 같이 적 용하였다. 식 (7)은 역세척 후 여재에 잔류된 고형물량 $(\mathrm{kg})$ 을 산정한 식으로, 운전시간 동안 유입된 고형물 총량에서 처리 수와 역세척 후 하부배출된 고형물 총량에 대한 물질수지 식 은 식 (7), (8)과 같다.

Residual in media $(\mathrm{kg})$

$=Q_{I} C_{I} \Delta_{T}-Q_{I} C_{I} \Delta_{T}-\left(C_{U 1} V_{U 1}+C_{U 2} V_{U 2}\right)$

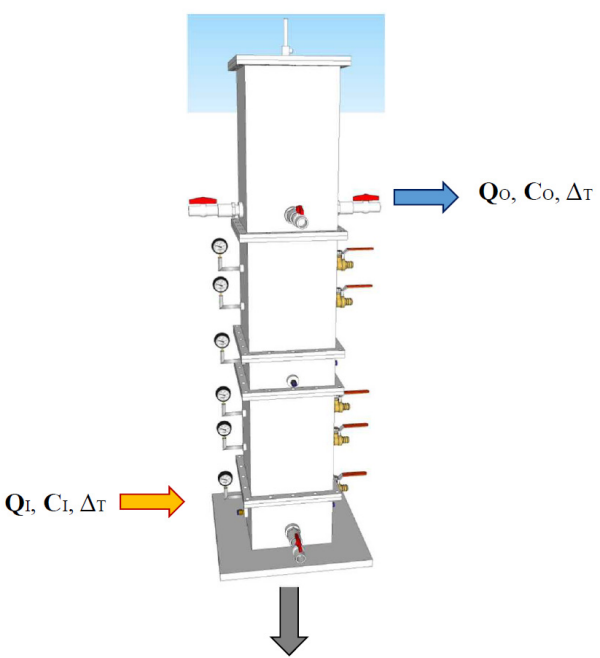

$\mathrm{CU}_{1}, \mathrm{~V}_{\mathrm{U} 1}+\mathrm{CU}_{\mathrm{U} 2}, \mathrm{~V}_{\mathrm{U} 2}$

Fig. 18. Backwashing effect analysis with solids mass balance. 


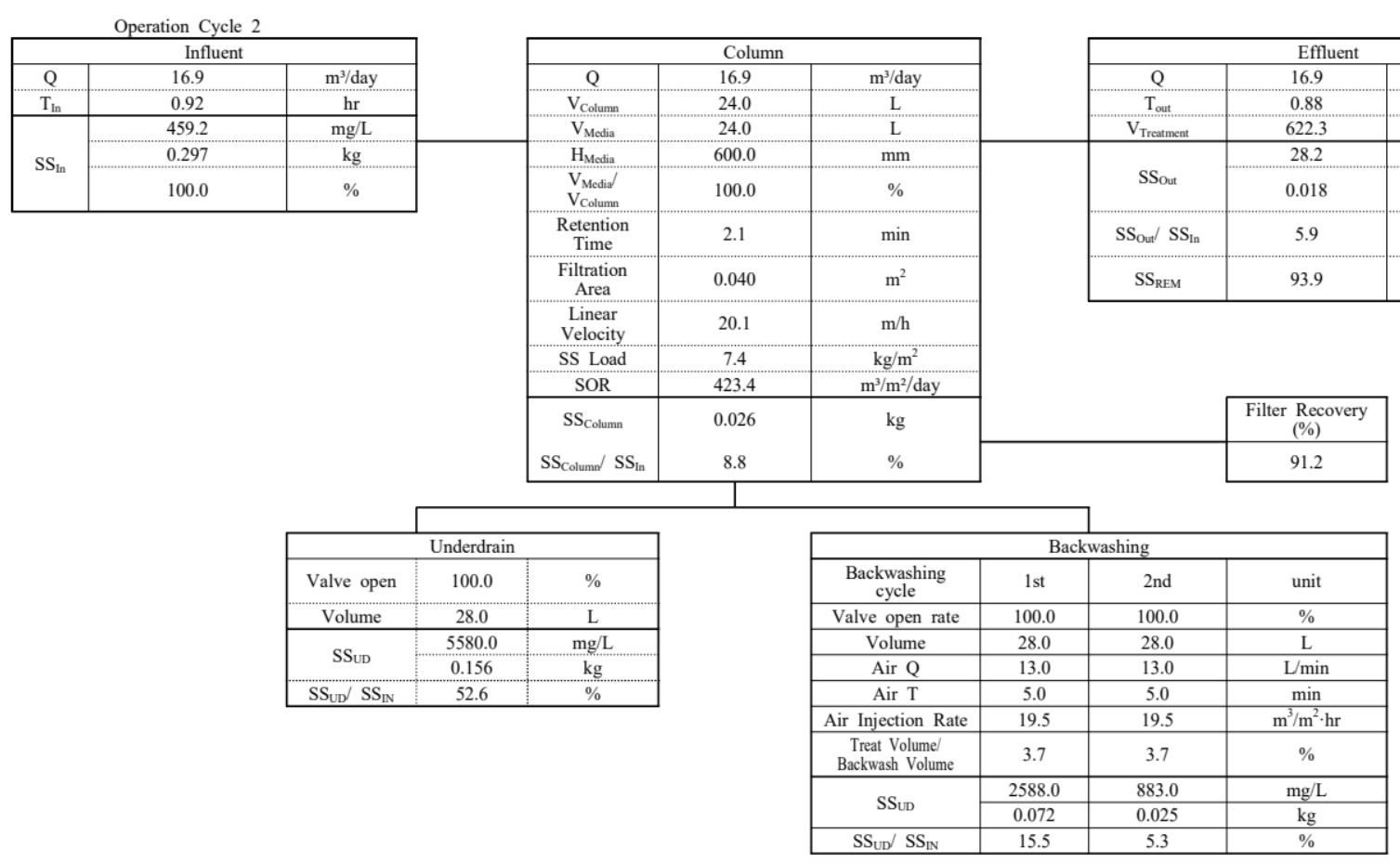

Fig. 19. Analysis of backwashing effect using mass balance analysis for residual SS.

Recovery rate of media backwashing

$=[1-$ Residual $(\mathrm{kg}) /$ Influent $(\mathrm{kg})] \times 100 \%$

역세척 후 여재에 남아 있는 고형물질량을 유입 고형물질 총량으로 나누어 여재 여과 회복력(\%)으로 나타내었다. Fig.

19는 2 Cycle 운전에 대한 역세척 실시 후 여재에 잔류된 고 형물질량을 산정하는 과정을 나타낸 것이다.

Fig.19에서 2 Cycle 운전 후 1차 역세척 과정에서 유입수 $\mathrm{SS}(\mathrm{kg})$ 에서 대한 잔류수 배수에 의해 제거된 SS $(\mathrm{kg})$ 분율, $\mathrm{SS}_{\mathrm{BW} 1} / \mathrm{SS}_{\mathrm{IN}}(\%)$ 는 $15 \%$ 로 산정되었다. 2 차 역세척 과정에서 유입수 SS $(\mathrm{kg})$ 에서 대한 역세척 잔류수 배수에 의해 제거된 $\mathrm{SS}(\mathrm{kg})$ 분율, $\mathrm{SS}_{\mathrm{BW} 2} / \mathrm{SS}_{\mathrm{IN}}(\%)$ 은 $5.3 \%$ 로 산정되었다. 1차 역세 척이 2 차 역세척보다 여재 내 고형물 제거가 많이 되는 것으 로 분석되었다. 섬유볼 여재 상향류 여과장치에 유입된 $\mathrm{SS}$ 량 $(\mathrm{kg})$ 에 대한 역세척 후 여과조내 $\mathrm{SS}$ 잔량 $(\mathrm{kg})$ 백분율은 1 Cycle 5 Cycle 운전에 대해 각각 $13.9 \%, 8.8 \%, 3.2 \%, 15.1 \%$, $14.6 \%$ 로 분석되었다. 각 Cycle별 역세척 후 여재 여과 회복율 은 각각 $86.1 \%, 91.2 \%, 96.8 \%, 84.9 \%, 84.4 \%$ 로 평균 $88.7 \%$ 로 분석되었다.

\section{4. 결론}

여과형 비점오염 처리장치에는 입자성 여재, 섬유사 여재, 분리막 등 다양한 재질, 소재의 여재를 적용하고 있다. Reddy 등이 ${ }^{7)}$ 제시한 비점오염 여재조건에 추가적으로, 여재는 무엇 보다 처리효율이 우수하고, 비중이 작아 교체가 용이하고, 가
격이 저렴하고, 역세척 후 여과회복율이 우수할 것을 제안한 다. 따라서, 여과형 비점오염 처리장치에서 발생하는 막힘, 처리효율 감소, 여재 교체비용 등의 유지관리상 문제점에 대 한 대안으로 역세척 효과가 우수한 여재 선정과 개발이 중요 하다.

본 연구에서는 비중이 작고, 상대적으로 비용이 저렴한 섬 유볼 여재를 상향류 여과방식으로 적용하여 처리특성과 역세 척효과, 입경분포 및 역세척 후 잔류 고형물질량을 측정하여 여재의 성능을 분석하였다. 기존 역세척 방식과는 다르게 상 단, 하단 카트리지 형태 여과칼럼 중간에 역세척 장치를 추가 하였고 각 여재의 처리성능을 분석하였다. 비점오염 표준시 료를 사용하여 고농도, 중농도, 저농도로 주입하여 수면적부 하율, 체류시간, 손실수두 등 운전조건에 따른 처리효율 변화 등을 분석하였다. 하단 여재 처리효율 결과를 기초로 유출수 의 SS, 탁도 농도를 예측할 수 있는 식을 산정하였다. 또한, 고형물질 물질수지를 분석하여 역세척에 의한 여재 회복율을 분석하였다. 실험실 규모 처리장치 운전을 기초하여 다음과 같은 주요 결론을 도출하였다.

$1 \sim 5$ Cycle 전체운전 동안 여과칼럼 평균체류시간은 1.99 $\mathrm{min}$, 수두손실은 평균 $7.20 \mathrm{~cm}$ 로 짧은 수리학적 체류시간과 낮은 손실수두 운전이 가능하다. SOR $20 \mathrm{~m}^{3} / \mathrm{m}^{2} / \mathrm{hr} \quad(=480$ $\mathrm{m}^{3} / \mathrm{m}^{2} /$ day) 운전조건에서 유출수 탁도 약 $15 \mathrm{NTU}, \mathrm{SS} 20$ $\mathrm{mg} / \mathrm{L}$ 이하로 낮은 유출수 수질확보가 가능하였다. 유입수 $\mathrm{SS}$ 농도가 낮을수록 유출수 탁도, $\mathrm{SS}$ 농도는 낮아지는 경향을 나타내어 유입수를 전처리 후 SS 농도를 저감시킨 후 여과할 경우 낮은 유출수 농도로 처리가 가능할 것으로 판단된다. 
$\mathrm{SOR}$ 을 $32.8 \mathrm{~m}^{3} / \mathrm{m}^{2} / \mathrm{hr}$ 까지 증가시켜 운전에서 수두손실이 $8.19 \mathrm{~cm}$ 까지 증가하였지만 비점오염 여과시설 수두손실 10 $\mathrm{cm}$ 미만을 나타내었다. 유출수 탁도와 SS 제거효율 관계를 분석한 결과 유출수 탁도 제거효율과 $\mathrm{SS}$ 제거효율과의 상관 계수는 0.90 으로 분석된 바, 연속적인 모니터링이 가능한 탁 도가 운전상태 평가에 주요 인자로 활용이 가능하다. 또한, $\mathrm{SOR}$ 과 탁도 및 $\mathrm{SS}$ 제거효율과 상관계수는 각각 $0.79,0.72$ 로 분석되어 처리장치의 안정적 처리를 위한 SOR범위를 파악할 수 있다. 하단 여재 처리효율과 유입수 수질을 이용하여 유출 수 수질을 예측한 결과 상관계수는 탁도 $0.76, \mathrm{SS}$ 0.74로 분석 되었다.

유입수 평균입경은 평균 $0.67 \mu \mathrm{m}$, 중간 유출수는 평균 0.79 $\mu \mathrm{m}$, 유출수는 평균 $0.59 \mu \mathrm{m}$ 로 분석되었다. 여과과정에서 여 재 내 포획되어 입경이 감소하는 경향과 여재 공극 내에서 입자 간 충돌, 흡착 등으로 입자 간에 결합이 발생하여 유입 수 입경보다 큰 유출수 입경분포가 나타나는 것으로 판단된 다. SEM 분석결과 여과 후에는 다양한 입경을 가진 입자들이 여재에 축적되어 있는 것으로 확인하였고, 역세척 후에는 여 재 내 매우 미세한 입자들은 제거되지 않고 섬유사에 부착되 어 잔류되는 것으로 나타났다. 잔류고형물 물질수지 분석을 통해 산정한 섬유볼 여재 여과 회복율은 평균 $88.7 \%$ 로 역세 척 효과가 우수한 것으로 평가된다.

향후 섬유볼 여재의 압축비 변화, 다양한 비점오염 입경분 포, 극단적인 수면적부하율 변화 등에 따른 처리효율 특성, 역세척효율 극대화 방안 등에 대한 지속적 실험과 분석을 수 행하고자 한다.

\section{Acknowledgement}

이 논문은 한국교통대학교 산학협력단과 자연환경(주)의 지원을 받아 수행하였습니다.

\section{References}

1. J. J. Sansalone, J. Y. Kim, Suspended particle destabilization in retained urban stormwater as a function of coagulant dosage and redox conditions, Water Res., 42(4-5), 909-922(2008).

2. J. H. Lee, K. W. Bang, Performance evaluation of backwash hydrodynamic separator filter for treatment of micro particles, J. Korean Soc. Environ. Eng., 34(10), 694-701(2012).

3. J. H. Lee, E. M. Gwon, S. H. Yang, Evaluation on performance and backwashing effect of filter media for treatment of nonpont pollution, J. Korean Soc. Environ. Eng., 41(6), 337-345(2019).

4. C. S. Lim, D. G. Kim, S. O. Ko, Evaluation of downflow granular media filtration for stormwater treatment, J. Korean
Soc. Environ. Eng., 34(10), 684-693(2012).

5. S. H. Kim, E. M. Gwon, S. S. Park, S. J. Joh, C. H. Lim, S. H. Kang, Identification of operating parameters in auto-discharging filter system for treatment of urban storm water, J. Korean Soc. Water Wastewater, 24(4), 377-386 (2010).

6. R. Shimazu, O. Matsushima, T. Meguro, Study on the simplified fiber filtration for CSO control, $11^{\text {th }}$ International Conference on Urban Drainage, United Kingdom, pp. 1-10 (2008).

7. R. R. Krishna, F. Reddy, X. Tao, S. Dastgheibi, Mixed-media filter system for removal of multiple contaminants from urban storm water: large-scale laboratory testing, J. Hazard. Toxic Radioact. Waste, 18(3), 04014011(2014).

8. Y. S. Kim, C. I. Jung, J. I. Oh, Y. M. Yoon, Feasibility study on removal of total suspended solid in wastewater with compressed media filter, J. Korean Soc. Environ. Eng., 36(2), 84-95(2014).

9. P. Gao, G. Xue, X. S. Song, Z. H. Liu, Depth filtration using novel fiber-ball filter media for the treatment of high-turbidity surface water, Sep. Purif. Technol., 95, 32-38 (2012).

10. O. Caliskaner, G. Tchobanoglous, Optimization of compressible medium filter for secondary effluent, Water Pract. Technol., 4(1), 1-8(2009).

11. T. Takasou, T. Tashiro, K. Sasaoka, M. Katou, High-speed fiber filter for a combined sewerage system to reduce discharge load, Ninth iternational conference on Urban Drainage, Urban Drainage, Oregon, pp. 1-12(2002).

12. C. Visvanathan, D. R. I. B. Werellagama, R. B. Aim, Surface water pretreatment using floating media filter, J. Environ. Eng., 122(1), 25-33(1996).

13. K. S. Choi, Application of flexible fiber filter for recycling water treatment in aquaculture system, J. Ins. Marine Industry, 17, 9-18(2004).

14. J. H. Im, H. K. Kim, J. J. Lee, T. S. Moon, M. K. Jeong, H. J. Woo, C. W. Kim, The effect on treatment performance of fiber filter under various packing-density and filtration velocity, J. Korean Soc. Environ. Eng., 28(2), 216-222(2006).

15. S. M. Son, J. Warangkana, K. Y. Park, C. H Park, Performance of fiber media filter device for combined sewer overflows treatment, J. Korean Soc. Water Wastewater, 24(2), 231-236(2010).

16. A. J. Kang, S. H. Jeong, S. M. Yoon, J. I. Oh, N. S. Park, Smart filter system performance for removal of contaminants from urban storm water: lab and pilot scale tests, J. Korean Soc. Environ. Eng., 41(3), 156-165(2019).

17. Polypropylene, polyethylene, https://ko.wikipedia.org/wiki (2021).

18. Ministry of Environment, Installation and management of nonpoint pollution control facilities operation manuals, Ministry of Environment, pp. 8-10(2017). 


\section{Declaration of Competing Interest}

The authors declare that they have no known competing financial interests or personal relationships that could have appeared to influence the work reported in this paper.

\section{Authors and Contribution Statement}

\section{Junho Lee}

Division of Civil, Environmental \& Urban-Transportation Engineering, Korea National University of Transportation, Professor, ORCID (0000-0002-2742-9814: Conceptualization, Data curation, Data analysis, Methodology, Project administration, Supervision, Validation, Visualization, Writing - original draft, Writing - review and editing.

\section{Daesik Song}

Jayeon Environment, Co., Ltd., CEO, ORCID (시 0000-0002-36180336: Conceptualization, Funding acquisition, Project administration, Resources, Validation. 